\title{
BRIP1 overexpression is correlated with clinical features and survival outcome of luminal breast cancer subtypes
}

\author{
Ishita Gupta ${ }^{1}$, Allal Ouhtit' ${ }^{2}$, Adil Al-Ajmi ${ }^{3}$, Syed Gauhar A Rizvi ${ }^{4}$, Hamad Al-Riyami', Marwa Al-Riyami ${ }^{5}$ and \\ Yahya Tamimi ${ }^{6}$ \\ ${ }^{1}$ Department of Genetics, College of Medicine and Health Sciences, Sultan Qaboos University, Alkoudh, Sultanate of Oman \\ ${ }^{2}$ Department of Biological and Environmental Sciences, College of Arts and Sciences, Qatar University, Doha, Qatar \\ ${ }^{3}$ Department of Surgery, College of Medicine and Health Sciences, Sultan Qaboos University, Alkoudh, Sultanate of Oman \\ ${ }^{4}$ Department of Family Medicine and Public Health, College of Medicine and Health Sciences, Sultan Qaboos University, Alkoudh, Sultanate of Oman \\ ${ }^{5}$ Department of Pathology, College of Medicine and Health Sciences, Sultan Qaboos University, Alkoudh, Sultanate of Oman \\ ${ }^{6}$ Department of Biochemistry, College of Medicine and Health Sciences, Sultan Qaboos University, Alkoudh, Sultanate of Oman
}

Correspondence should be addressed to Y Tamimi: yahyatam@squ.edu.om

\begin{abstract}
In Oman, breast cancer is most common, representing approximately more than $25 \%$ of all cancers in women. Relatively younger populations of patients (25-40 years) present surprisingly with an aggressive phenotype and advanced tumor stages. In this study, we investigated differential gene expressions in Luminal A, Luminal B, triple-negative and Her2+ breast cancer subtypes and compared data to benign tumor samples. We identified a potential candidate gene BRIP1, showing differential expression in the four breast cancer subtypes examined, suggesting that BRIP1 has the profile of a useful diagnostic marker, suitable for targeted therapeutic intervention. RT-qPCR and Western blotting analysis showed higher BRIP1 expression in luminal samples as compared to triple-negative subtype patient's samples. We further screened BRIP1 for eventual mutations/SNPs/deletions by sequencing the entire coding region. Four previously identified polymorphisms were detected, one within the $5^{\prime}$-UTR region (c.141-64G >A) and three in the BRCA-binding domain (c.2755T > C, c.2647G >A and c.3411T>C). Kaplan-Meier analysis revealed that patients with overexpression of BRIP1 displayed a poor survival rate $(P<0.05)$. BRIP1 has a dual function of an oncogene and a tumor suppressor gene in addition to its role as a potential biomarker to predict survival and prognosis. Data obtained in this study suggest that BRIP1 can plausibly have an oncogenic role in sporadic cancers.
\end{abstract}
Key Words
- breast cancer
- BRIP1
- oncogene
- overexpression
- biomarkers

\section{Introduction}

Breast cancer is the most common among women, affecting $25 \%$ of female population worldwide and more than a million new cases are diagnosed every year (1). Environmental components are considered serious risk factors, whereas genetic factors remain modest and contribute to only $20 \%$ of the cases. In Oman, a Middle Eastern country (2), breast cancer is the most common cancer among women and represents about $25 \%$ of all females' cancers (3), affecting frequently a relatively younger Omani population ( $\sim 67 \%$ are below the age of 50 years) as compared to women in other parts of the world (4).

The rapid advancement in molecular biologyrelated technologies has contributed significantly to our understanding of mechanisms underlying the setup of breast cancer. A panel of relevant genes suspected to http://www.endocrineconnections.org https://doi.org/10.1530/EC-17-0173 (c) 2018 The authors Published by Bioscientifica Ltd
Endocrine Connections (2018) 7, 65-77 
play a key role in the pathogenesis of breast cancer was identified, and their mutations being implicated in the development of breast cancer. These include p53, BRCA1 and BRCA2, ATM and PTEN; all found to be associated with breast cancer. Screening for germline mutations in these genes, especially BRCA1 stands out as the major breast cancer gene commonly used in the diagnosis of breast cancer (5). Nonetheless, breast cancer remains a complex disease involving several factors, and therefore, may involve a cocktail of genes alterations contributing to the onset and progression of breast cancer. Although, several genetic alterations have been identified in breast cancer, the frequency of different gene aberrations remains however quite low due to either oncogene amplifications or tumor suppressor gene (TSG) mutations/deletions (6).

Among the frequently mutated oncogenes, HER2 (20-30\%), c-MYC (1-94\%), RAS (<5\%), Cyclin D1 (>50\%), Cyclin E (13-20\%) and Estrogen receptor (ER $\alpha$ and ER $\beta$ ) (60\%) were reported, whereas BRCA genes (BRCA1 and BRCA2) (40-80\%), RB (30\%), TP53 (56-90\%) and PTEN (25-50\%) are the tumor suppressor genes (TSG) reported to be implicated. Mutations in the above genes, especially $B R C A 1 / 2$ in the majority of sporadic cases are rare and fail to explain these cases $(7,8)$, involving somatic mutations or variants of low penetrance sequences in a particular genetic background. Furthermore, several studies showed that lack or low expression levels of BRCA protein play a crucial role in the development of sporadic breast tumors $(9,10)$. Based upon the relative risk, breast cancer predisposing genes are categorized into high (BRCA1/2, TP53, PTEN, CDH1), moderate (ATM, CHEK2, BRIP1, PALB2) and low (MAP3K1, FGFR2, LSP1, CASP8) penetrance genes $(11,12)$.

Interestingly, in Oman, breast cancer diagnosis, in general, reveals aggressive subtype and advanced stages (stage III or IV) of breast tumors, likely due to either biological aggressive subtypes or a low index of suspicion and delayed diagnosis $(4,13)$. Breast cancer affecting younger female population remains intriguing; $<50$ years compared to 63 years for counterparts in the West $(14,15)$. This could be explained by a complex interaction between genetic background and environmental factors (16), which is consistent with a previous Lebanese and Saudi study (17), indicating higher proportion of young breast cancer in the Middle East when compared to Western countries. Usually, breast cancers in younger population tend to be more aggressive in nature and are associated with unfavorable prognosis when compared to women having the disease at later stages $(15,18,19,20)$.

http://www.endocrineconnections.org https://doi.org/10.1530/EC-17-0173

() 2018 The authors Published by Bioscientifica Ltd
Based on the above observations related to sporadic cases, as well as the lack or the low BRCA1/2 expression, these sporadic cancers could possibly have the BRCAness phenotype $(8,21)$. Therefore, we hypothesized that a subset of genes are directly or indirectly involved with BRCA proteins during the transition from the normal to the cancerous phenotype. We investigated gene expression differences in human breast cancer and identified genes with a role in the onset of breast cancer either independently or in association with BRCA1/2, such as the role played by genetic modifiers (22) that could represent useful diagnostic markers or targets for therapeutic purposes. One potential candidate gene interacting with $B R C A 1 / 2$ to regulate DNA repair and cell cycle was identified as BRIP1 gene, displaying 5-fold expression in the breast tumors as compared to the normal/benign tissue.

\section{Materials and methods}

\section{Subject and sample collection}

This research was approved by the local Research Ethics Committee at the Sultan Qaboos University (SQU), and written informed consent was obtained from each participant.

Following a predefined protocol, we recruited 50 BC patients, and 30 healthy individuals and/or carriers of benign tumors from January 2012 to April 2014 underwent biopsy and breast cancer surgery. Breast cancer was confirmed by biopsy reports as well as pathologically by molecular tests including estrogen receptor (ER), progesterone receptor (23), Her2 and Ki67 tests in addition to a histological examination using immunohistochemistry. Her2 status was determined using fluorescence in-situ hybridization (FISH). Breast tissue samples were collected during biopsy and mastectomy/ lumpectomy in cryo-vials containing RNAlater solution (Ambion, ThermoFisher Scientific) and stored at $-80^{\circ} \mathrm{C}$ until use.

Based on the patient information, the cases were classified into the four molecular subtypes as Luminal A, Luminal B, Her2+ and triple-negative BC cases.

Patients below the age of 10 or above 90 years, who had undergone previous chemotherapy, radiotherapy or mastectomy, and had chronic use of corticosteroids or non-steroidal anti-inflammatory drugs, were excluded from this study. 


\section{Cell lines and tissue culture}

Two different breast cancer cell lines (MCF-7 and MDA-MB-231) derived from females were purchased from American Type Culture Collection (ATCC) and were investigated for their BRIP1 expression. These cells represent different grades and subtypes of breast cancer; MCF-7 represents the luminal subtype, while MDA-MB-231 represents the triple-negative subtype $(1,2)$. Cell lines were grown and expanded in DMEM medium (Gibco, Life Technologies) supplemented with 10\% fetal bovine serum (FBS; Invitrogen, Life Technologies), 1\% PenStrep antibiotic (Invitrogen, Life Technologies) at $37^{\circ} \mathrm{C}$ and $5 \%$ $\mathrm{CO}_{2}$ atmosphere.

\section{Preparation of RNA samples and microarray analysis}

RNA was harvested from the 50 tumor and 30 benign/ normal breast tissues using the RNeasy Mini Kit (Qiagen) according to the manufacturer's instructions. Harvested RNA was assessed for degradation as well as quantity and purity, then aliquoted and stored at $-80^{\circ} \mathrm{C}$.

For microarray studies, we carried out analysis for each molecular subtypes of breast cancer (Luminal A, $n=4$, Luminal $\mathrm{B}, n=4$, Her2+, $n=2$, triple negative, $n=2$ ) compared to matching controls obtained from the same patients in triplicate using the Human Genome U133 plus 2.0 GeneChip oligonucleotide arrays (Affymetrix). The chip contained pairs of matched/mismatched 25-mer oligonucleotide probes for over 47,000 transcripts of known genes.

\section{Quantitative RT-PCR analysis (RT-qPCR)}

RT-qPCR was used to detect BRIP1 mRNA in breast cancer cell lines as well as tumor tissue samples (42 tumor and 21 normal/benign breast tissue samples). cDNA synthesis was carried out using High-Capacity cDNA Reverse Transcription Kit (Applied BioSystems) according to the manufacturer's protocol. Briefly, 200 ng of total RNA was reverse transcribed using the following program: $25^{\circ} \mathrm{C}$ for $10 \mathrm{~min}, 37^{\circ} \mathrm{C}$ for $120 \mathrm{~min}$ and $85^{\circ} \mathrm{C}$ for $5 \mathrm{~min}$, followed by incubation at $4^{\circ} \mathrm{C}$.

RT-qPCR was performed using TaqMan reagents according to the manufacturer's protocol. Briefly, $10 \mu \mathrm{L}$ of TaqMan Expression Master Mix were added to $100 \mathrm{ng}$ of cDNA and $1 \mu \mathrm{L}$ of TaqMan Gene Expression Assay containing primers and probes (BRIP1 and GAPDH, Thermo Scientific Fisher), appropriate volume of water was added to bring the total volume to $20 \mu \mathrm{L}$. RT-qPCR was then carried out in the ABI 7500 Fast real-time PCR machine (Applied Biosystems) using the following program: UNG incubation at $50^{\circ} \mathrm{C}$ for $2 \mathrm{~min}$, polymerase activation at $95^{\circ} \mathrm{C}$ for $20 \mathrm{~s}$, followed by 40 PCR cycles of denaturation at $95^{\circ} \mathrm{C}$ for $30 \mathrm{~s}$ and annealing/elongation at $60^{\circ} \mathrm{C}$ for $30 \mathrm{~s}$. All reactions were performed in triplicates and the relative expression levels of BRIP1 were calculated by normalizing the cycle threshold values of BRIP1 with those of GAPDH. Relative expression of BRIP1 was analyzed in each molecular subtype, using the comparative CT method.

\section{Western blot}

Western blot was performed in breast cancer cell lines and tissue samples (42 tumor samples and 21 benign samples).

Samples were lysed in RIPA buffer supplemented with $0.1 \mathrm{mmol} / \mathrm{L}$ of a protease inhibitor cocktail, sodium orthovanadate and phenylmethylsulfonylfluoride (PMSF) (Santa Cruz Biotechnology). The lysate was incubated on ice for $30 \mathrm{~min}$ and vortexed briefly every $10 \mathrm{~min}$, then centrifuged at $17,000 \boldsymbol{g}$ for $15 \mathrm{~min}$ to collect the proteins. The final protein concentration in the supernatant was determined using the Bradford Protein Assay Reagent (Pierce).

Equal amounts of protein $(\sim 40 \mu \mathrm{g})$ were boiled for $5 \mathrm{~min}$ in an equal volume of reducing buffer, resolved on $8 \%$ polyacrylamide gels and electroblotted onto nitrocellulose membranes. Membranes were probed with an anti-BRIP1 (1:500 dilution, Abcam: abID\#151509) and anti- $\beta$-actin primary antibodies (1:200 dilution, Santa Cruz Biotechnology), followed by a goat anti-rabbit IgG-HRP (1:10,000 dilution, Santa Cruz Biotechnology) secondary antibody. Immunoreactivity was detected using chemiluminescence as recommended by the manufacturer (Pierce Biotechnology).

In order to obtain a relative quantification of gene expressions, images acquired from Western blotting were analyzed using Image J software. The intensity of the BRIP1 bands relative to the $\beta$-actin bands were used to calculate a relative expression of this gene in each cell line.

\section{PCR amplification and sequencing}

Breast tissue samples (50 tumors and 30 normal/benign tissues) were collected from patients and genomic DNA was isolated using the QiAMP DNeasy Mini Kit (Qiagen) according to the manufacturer's instructions. The primers were designed by Primer3 software and 
tested for specificity using public databases (Human Genome NCBI and BLAST analysis) (3). The primers used were also described in previous studies $(4,5)$ and obtained from Metabion International $A G$ (Steinkirchen, Germany).

The full coding sequence of the BRIP1 gene was amplified using primers specific for each of the 20 exons (Table 1). Amplification included an initial denaturation at $95^{\circ} \mathrm{C}$ for $7 \mathrm{~min}$, followed by 35 cycles composed of denaturation at $95^{\circ} \mathrm{C}$ for $30 \mathrm{~s}$, annealing at temperature ranging from 50 to $62^{\circ} \mathrm{C}$ depending on each primer's melting temperature (Table 1 ) for $30 \mathrm{~s}$ and an elongation at $72^{\circ} \mathrm{C}$ for $30 \mathrm{~s}$. Samples were ultimately incubated for $10 \mathrm{~min}$ at $72^{\circ} \mathrm{C}$ for a final extension. The PCR product from each exon was resolved by using $1.5 \%$ agarose gel electrophoresis.

To determine whether BRIP1 was mutated in breast cancer, PCR products were sequenced using the ABI BigDye Terminator v3.1 Cycle Sequencing Kit (Applied Biosystems). The conditions of the sequencing reaction included 25 cycles at $96^{\circ} \mathrm{C}(10 \mathrm{~s}), 60^{\circ} \mathrm{C}(5 \mathrm{~s}), 60^{\circ} \mathrm{C}(4 \mathrm{~min})$ and $4^{\circ} \mathrm{C}$ (holding temperature). Sequencing data analysis was performed using the Chromas Pro version 1.7.7 software, to interpret the sequencing results by comparing the normal sequence of the targeted gene BRIP1 to the tested sequence.

\section{Statistical analysis}

Statistical analyses were performed using Statistical Package for the Social Sciences (SPSS, version 23). T-test was performed and graphs were plotted using GraphPad Prism Software (version 7.00) to determine fold changes. The significance was attributed to $P$ values lower than $5 \%(P<0.05)$.

Continuity correction chi-square test (50 tumors and 30 normal/benign breast tissues) was performed to analyze any potential associations between the polymorphisms and breast cancer disease.

Kaplan-Meier method was used for survival analysis and significant differences between gene expression and overall survival was compared using the log-rank test. Based on a previous study (6), breast cancer patients were classified into high or low expressing group according to whether the expression of BRIP1 gene was greater than the median expression of BRIP1.

\section{Results}

\section{Clinical and pathological characteristics of patients}

Fifty female patients with a pathologically confirmed diagnosis of invasive breast cancer were included.

Table 1 Primers and annealing temperatures $\left(T_{\mathrm{a}}\right)$ for $B R I P 1$ coding exons.

\begin{tabular}{|c|c|c|c|c|}
\hline \multirow[b]{2}{*}{ Exon } & \multicolumn{2}{|c|}{ Primer sequence $\left(5^{\prime} \rightarrow 3^{\prime}\right)$} & \multirow[b]{2}{*}{$\boldsymbol{T}_{\mathrm{a}}\left({ }^{\circ} \mathrm{C}\right)$} & \multirow[b]{2}{*}{ Product size $(b p)$} \\
\hline & Forward & Reverse & & \\
\hline \multicolumn{5}{|l|}{ BRIP1 } \\
\hline 1 & CCGGGACTGGTTGATTCCTG & GGACTTCCCTCCGACTTGC & 62 & 305 \\
\hline 2 & TTCTTTGTAAGGCGTGTCTCAA & CAAATACTCAATGTACTTTATGGGTCA & 54 & 246 \\
\hline 3 & AACTTCAGATGGAGAGAGACCTTTA & CTGTATTATATTTTCTCAGATCCCAGT & 54 & 241 \\
\hline 4 & CTGGGTGAACTGGGCTGTAG & GGATTTTTGACCACTCTGTGC & 62 & 250 \\
\hline 5 & TCTTCTAGAAAAATTGCCTACCTG & GACTACCATGTTCAGCTGTAACTAACT & 54 & 299 \\
\hline 6 & GGCCTTTGAGAACAACTAGCC & TGGTTTAGAAAATTCCATATCTTCC & 54 & 481 \\
\hline 7 & TTCCATGTGAGGTTTGATAACG & GCAGTTAATTTGATTTTCCGAAG & 54 & 282 \\
\hline 8 & GCCTTGTGGCTTTAATGATG & CAACATTTACATCTCCATGAGTAGG & 54 & 349 \\
\hline 9 & TGAAATATCTTGCCTGCTGTTG & TTTAAATACTCTGGCATAATCAAACA & 55 & 249 \\
\hline 10 & GTGTGTGTAAGGATGATACTGGTT & TTGCTATATTTAACAATTCTGGGTTA & 54 & 268 \\
\hline 11 & TTTTCCAАTTСССТСССАAC & TGCTAGCATCCAAATTAGGCTAT & 58 & 286 \\
\hline 12 & TTGTATGTAGCTGGGTCATAGGTT & AAAATGCTGGTACTGAGCAAGA & 58 & 295 \\
\hline 13 & ACTTTGCCCAGCCTCTTCTA & TTACTTGCTGGCACTTCAGG & 50 & 375 \\
\hline 14 & TTCCATGCCTTTTTCAGG & GCATGCCAATGTTTAAAATGTA & 52 & 382 \\
\hline 15 & GCCGTAGTCACATTGGCTTA & AATTTATTTTCTTTTCACTCAGGATT & 55 & 261 \\
\hline 16 & TTTTCAAAATGACAAGAATAAGCA & GGGATCCCTGCAATTAACTTT & 58 & 362 \\
\hline 17 & TGAAAAACAAAATAAAATCTCTACCC & CCAGTTCCTATGGTTCCAGTT & 55 & 362 \\
\hline 18 & CTGTCCCACTGGAAAACTGG & CATGTTATGTGTTTTTCACCACAA & 54 & 456 \\
\hline 19 & GGTTACTTCACTAGAAAAAGCAAGTG & TCAAAGGTAAATGGGAAGAACTTT & 54 & 516 \\
\hline $20 a$ & GCAATTATGTTAGCTAGGAGCAGA & TCAAAATCTCTATTTGAAGTGGACTG & 55 & 305 \\
\hline $20 b$ & TGAACATCCGCTCTGTTCTG & TGCAATCCTCAGCTTTCACT & 55 & 328 \\
\hline $20 c$ & AACAATTCAGATTGCATTTTAGC & GAGTTTAACATAAGCATGATGAC & 55 & 295 \\
\hline
\end{tabular}

$\begin{array}{lr}\text { http://www.endocrineconnections.org } & \text { ○ } 2018 \text { The authors } \\ \text { https://doi.org/10.1530/EC-17-0173 } & \text { Published by Bioscientifica Ltd }\end{array}$

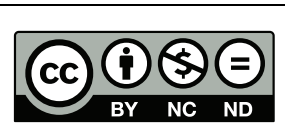

This work is licensed under a Creative Commons Attribution-NonCommercial-NoDerivatives 4.0 International License. 
The mean age of all patients was 46.54 (standard deviation (s.D.), \pm 15.8 ) years. Majority of patients (84\%) did not have any family history of breast cancer or any other cancer. Most of the patients (74\%) were pre-menopausal and $62 \%$ had less than 50 years old ( $\leq 50$ years). Axillary lymph nodes were found to be involved in $64 \%$ of patients (Table 2).

All patients had invasive ductal carcinoma except for three patients, with invasive lobular carcinoma and nine patients with metaplastic carcinoma. With respect to the hormone receptor, 35 (70\%) and 29 (58\%) of the patients (50 patients) expressed estrogen and progesterone receptors, respectively. Information regarding Her2/neu status was available for 45 patients and eighteen were Her2 positive. Status for Ki67 proliferative index was available for 20 patients, 3 of which had low $(<10 \%)$ proliferative index, 5 were borderline (10-20\%) and the remaining 12 had a high (>20\%) proliferative index of Ki67 (Table 2).

Table 2 Clinico-pathological characteristics of patients with breast cancer.

\begin{tabular}{|c|c|c|}
\hline Characteristics & $\begin{array}{c}\text { Number of } \\
\text { patients }\end{array}$ & $\begin{array}{c}\text { Percentage } \\
(\%)\end{array}$ \\
\hline \multicolumn{3}{|l|}{ Age (years) } \\
\hline$>50$ & 19 & 38 \\
\hline$\leq 50$ & 31 & 62 \\
\hline \multicolumn{3}{|l|}{ Site of breast lesion } \\
\hline Left & 32 & 64 \\
\hline Right & 18 & 36 \\
\hline \multicolumn{3}{|l|}{ Family history } \\
\hline Yes & 8 & 16 \\
\hline No & 42 & 84 \\
\hline \multicolumn{3}{|l|}{ Menopausal status } \\
\hline Pre-menopausal & 37 & 74 \\
\hline Post-menopausal & 13 & 26 \\
\hline \multicolumn{3}{|l|}{ Histology } \\
\hline Invasive ductal carcinoma & 38 & 76 \\
\hline Invasive lobular carcinoma & 3 & 6 \\
\hline Metaplastic carcinoma & 9 & 18 \\
\hline \multicolumn{3}{|l|}{ Lymph node involvement } \\
\hline Yes & 32 & 64 \\
\hline No & 18 & 36 \\
\hline \multicolumn{3}{|c|}{ Estrogen receptor (ER) status (50 patients) } \\
\hline $\mathrm{ER}+$ & 35 & 79 \\
\hline ER- & 10 & 30 \\
\hline \multicolumn{3}{|c|}{ Progesterone receptor (PR) status (50 patients) } \\
\hline PR+ & 29 & 58 \\
\hline PR- & 16 & 42 \\
\hline \multicolumn{3}{|c|}{ Her2 receptor status (45 patients) } \\
\hline Her2+ & 18 & 40 \\
\hline Her2- & 27 & 60 \\
\hline \multicolumn{3}{|c|}{ Ki67 proliferative index (PI) (20 patients) } \\
\hline Low $(<10 \%) \mathrm{PI}$ & 3 & 15 \\
\hline Borderline (10-20\%) PI & 5 & 25 \\
\hline High $(>20 \%) \mathrm{PI}$ & 12 & 60 \\
\hline $\begin{array}{l}\text { http://www.endocrineconnections.org } \\
\text { https://doi.org/10.1530/EC-17-0173 }\end{array}$ & $\begin{array}{r}\text { (๑) } \\
\text { Published by }\end{array}$ & $\begin{array}{l}2018 \text { The author } \\
\text { Bioscientifica Ltc }\end{array}$ \\
\hline
\end{tabular}

Based on their Her2/neu hormone receptor status available for 45 patients, they were categorized based on their molecular subtypes, Luminal A (20), Luminal B (14), Her2+ (5) and triple negative (5). Of the 50 patients, 6 were excluded from the study since their Her2/neu hormone receptor status was not available.

\section{Identification of BRIP1 as a target in Omani breast cancer patients}

To identify the potential genes that underpin the transition of benign to malignant breast tissue, we carried out a microarray gene expression profiling comparison of Omani breast cancer tissue samples from the four molecular subtypes (Luminal A, Luminal B, Her2+ and triple negative) and benign tissues. TAC suite and Ingenuity Pathway Analysis identified genes based on their functional annotations including development, cellular differentiation, proliferation, cytostasis in breast cancer. From all the four groups, BRIP1 (BRCA1interacting protein C-terminal helicase1) was identified as a potential $\mathrm{BC}$ candidate gene, showing an average of 5-fold overexpression (Fig. 1).

\section{Screening for mutations/SNPs in BRIP1 gene}

Screening for BRIP1 mutations/deletions by direct sequencing identified four polymorphisms. Sequential analysis of the promoter region, upstream of exon 1 , led to the identification of the previously reported polymorphism (c.-141-64G >A) (7). Furthermore, we identified three polymorphisms located within the BRCA1-binding domain; one of them was non-synonymous (c.2755T >C), while the other two were synonymous (c.2637G $>$ A and c. 3411 T $>C$ ). There was no significant association between the two polymorphisms and the presence of breast cancer $(P>0.05)$ (Table 3).

\section{Validation of BRIP1 by RT-qPCR and Western blot analyses}

To validate and confirm that BRIP1 is a potential target, we evaluated mRNA expression of BRIP1 using RT-qPCR on breast cancer cell lines (MCF-7 and MDA-MB-231) as well as breast tumor tissue samples (42 tumor samples) and compared to the expression in the 21 normal/benign breast tissue samples. BRIP1 expression was normalized to expression levels of GAPDH gene. Results showed, BRIP1 mRNA levels were 5.2-fold higher in MCF-7 and 1.5-fold higher in MDA-MB-231 $(P<0.05)$ (Fig. 2A), analysis in

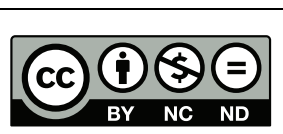
This work is licensed under a Creative Commons
Attribution-NonCommercial-NoDerivatives 4.0 International License. 


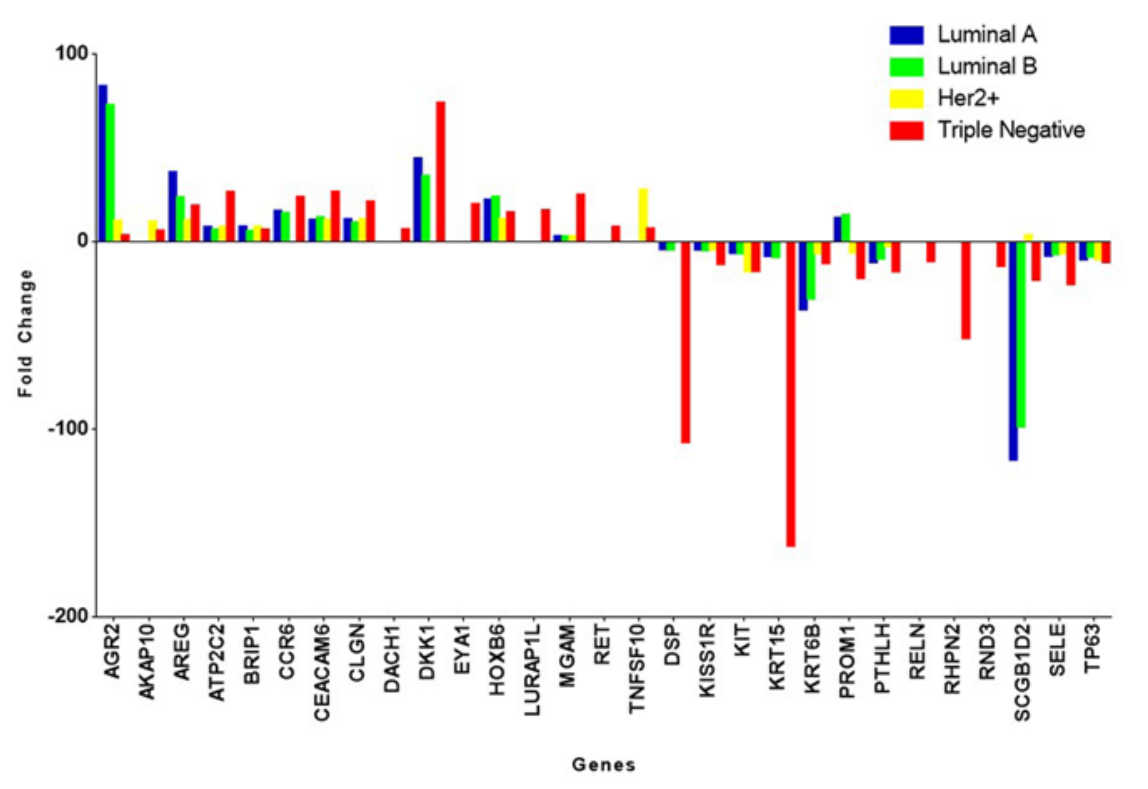

Figure 1

Representative bar graph indicating the expression of other genes including BRIP1 based on the tumor subtype. The blue bar indicates expression of genes in the Luminal A subtype, green indicates gene expression in Luminal B subtype, while yellow and red bars indicate gene expression in the Her2+ and Triple-negative subtypes, respectively. each molecular subtype showed Luminal A subtype had maximum overexpression of BRIP1 (6.5-fold) followed by Luminal B (5.2-fold). Both the Her2+ and triple-negative subtype had similar degree of BRIP1 expression (3.8-fold) as compared to the normal/benign tissue samples $(P<0.01$, Fig. 2B). We also performed, RT-qPCR based on the different grades of the breast tumor in comparison to the normal/ benign tissues and analysis showed BRIP1 expression to increase with increase in grade $(P<0.05$, Fig. 3$)$.

BRIP1 expression was further confirmed for the breast cancer cell lines as well as 42 tumor and 21 normal/benign tissue samples, at the protein levels by Western blotting analysis. Furthermore, MCF-7 displayed a 5.5-fold difference and MDA-MB-231 displayed a 2-fold increase in BRIP1 expression $(P<0.05$, Fig. $4 \mathrm{~A}$ and $\mathrm{B})$; similar to results obtained in each molecular subtype (Fig. 4). BRIP1 expression was highest in the Luminal A subtype (11.43-fold), followed by Luminal B (4.54-fold), triple-negative (4.86-fold) and Her2+ (5.6-fold) subtypes $(P<0.0001$, Fig. 5A and C). These results were consistent with our RT-qPCR results.

\section{Association of BRIP1 overexpression with the clinicopathological parameters in breast cancer}

BRIP1 expression was analyzed in breast tissue samples by RT-qPCR. The median expression of BRIP1 obtained by RT-qPCR recorded an 8 -fold expression and set as a threshold for overexpression. Patients were then classified into two groups according to their BRIP1 expression and the overall survival (OS) of patients vs BRIP1 expression was analyzed. A significantly worse overall survival (OS) in patients displaying high BRIP1 overexpression was obtained $(P<0.05$, Fig. 6). Survival analysis was also performed for the Luminal $A$ and Luminal B molecular subtypes and the OS of patients displaying high BRIP1 expression was significantly worse when compared to patients with low BRIP1 expression in both the Luminal A and Luminal B subtypes $(P<0.05$, Fig. 7A and B). We could not perform analysis for Her2+ and triple-negative subtypes due to the low number of patients.

Table 3 Identified variants in BRIP1 among breast cancer patients.

\begin{tabular}{|c|c|c|c|c|c|c|c|}
\hline Exon & Region & rs\# & $\begin{array}{l}\text { Nucleotide } \\
\text { change }^{a}\end{array}$ & $\begin{array}{l}\text { Effect on } \\
\text { protein }\end{array}$ & $\begin{array}{c}\text { Minor allele } \\
\text { frequency in } \\
\text { patients }\end{array}$ & $\begin{array}{l}\text { Frequency } \\
\text { in controls }\end{array}$ & $P$ value \\
\hline 1 & $5^{\prime}-U T R$ & rs2048718 & c. $-141-64 G>A$ & - & $35 / 50$ & $24 / 30$ & 0.711 \\
\hline 19 & BRCA1 binding domain & rs4986764 & c. $2755 \mathrm{~T}>\mathrm{C}$ & p.Ser919Pro & $40 / 50$ & $25 / 30$ & 0.393 \\
\hline 19 & BRCA1 binding domain & rs4986765 & c. $2637 \mathrm{G}>\mathrm{A}$ & p.Glu879Glu & $48 / 50$ & $29 / 30$ & 0.879 \\
\hline
\end{tabular}

aNumbering based on RefSeq NM_032043 (for all the variants within the coding region). For exonic variants, numbering starts at codon 1.

๑ 2018 The authors
Published by Bioscientifica Ltd

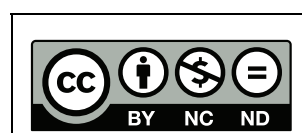

This work is licensed under a Creative Commons Attribution-NonCommercial-NoDerivatives 4.0 International License. 

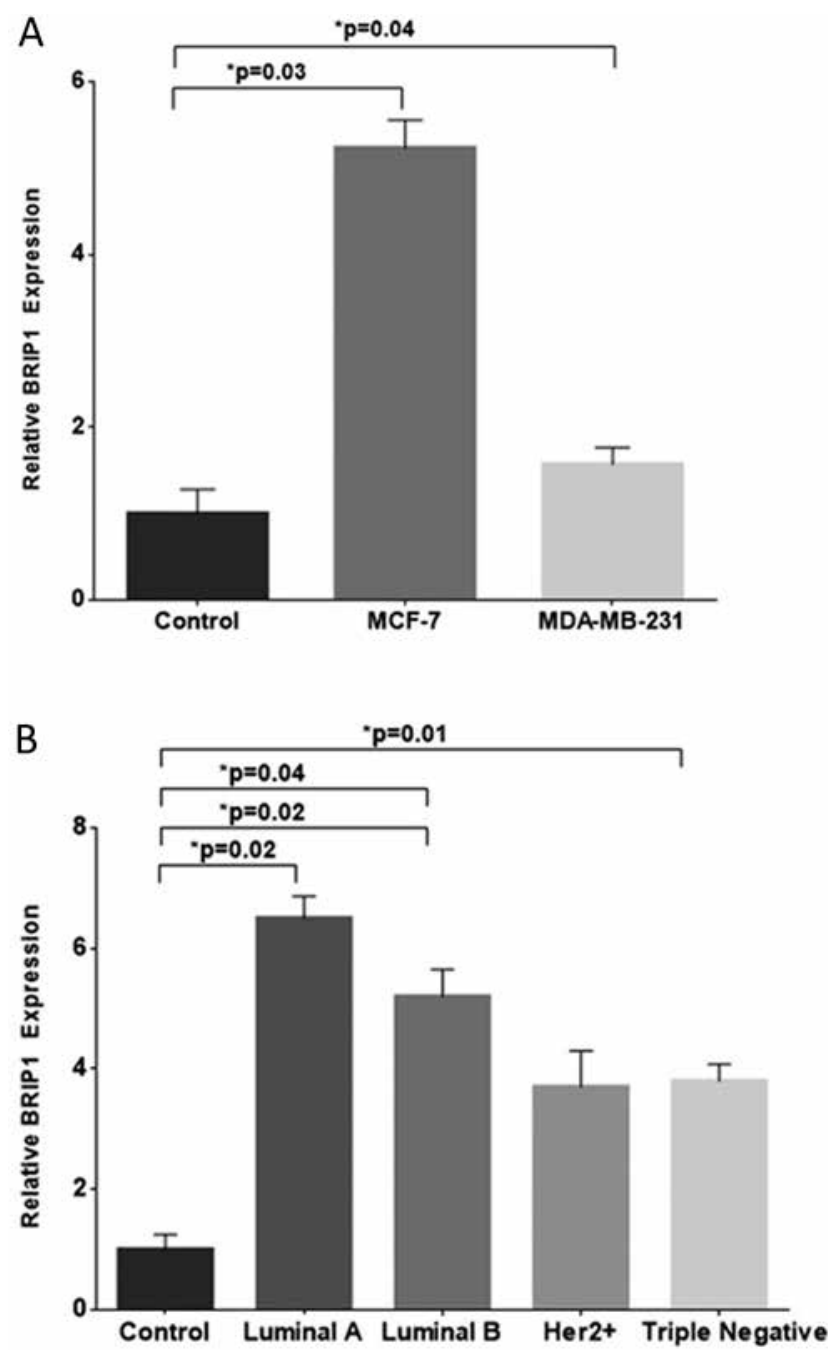

Figure 2

Validation of $B R I P 1$ expression by quantitative RT-PCR in breast cancer cell lines and breast tissue samples. RT-qPCR was carried out on cell lines and breast tissue samples. (A) MCF-7 had maximum BRIP1 expression with 5.2-fold, followed by a 1.5-fold expression for MDA-MB-231 in comparison to normal/benign breast tissue samples $(P<0.05)$. (B) Analysis in each molecular subtype showed Luminal $A$ subtype had maximum overexpression of BRIP1 (6.5-fold) followed by Luminal B ( 5.2 -fold). Both the Her2+ and Triple-negative subtype had similar degree of BRIP1 expression (3.8-fold) as compared to the normal/benign tissue samples $(P<0.01)$.

\section{Discussion}

In this study, we used microarray gene expression profiling to identify differentially expressed genes with a key role in the pathogenesis of breast cancer. Initial data analysis identified potential up/downregulated genes that might be associated with the specific signaling pathways promoting the transition from benign/normal breast tissue to malignant tumor (Fig. 1, $q$-value $<0.01)$.

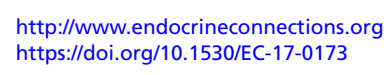

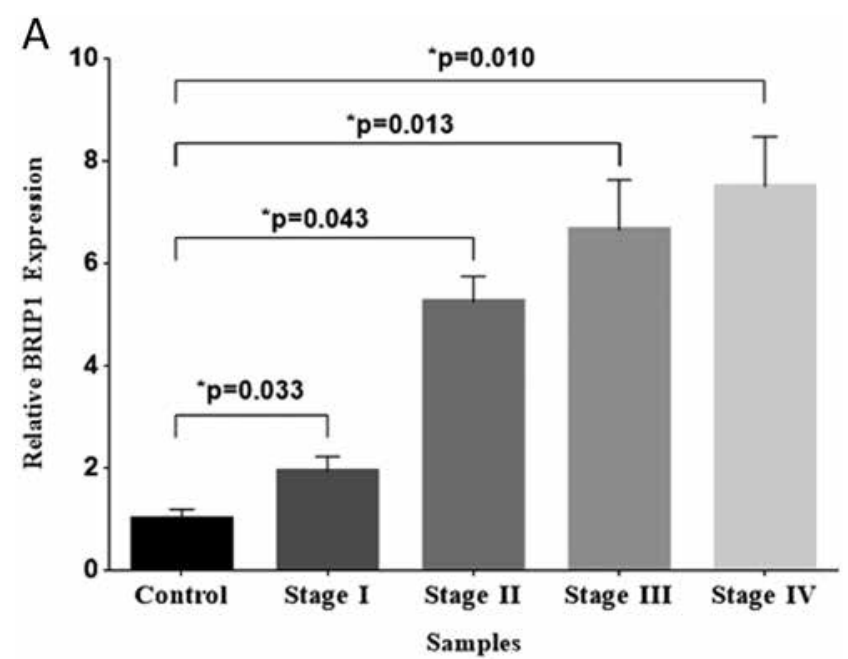

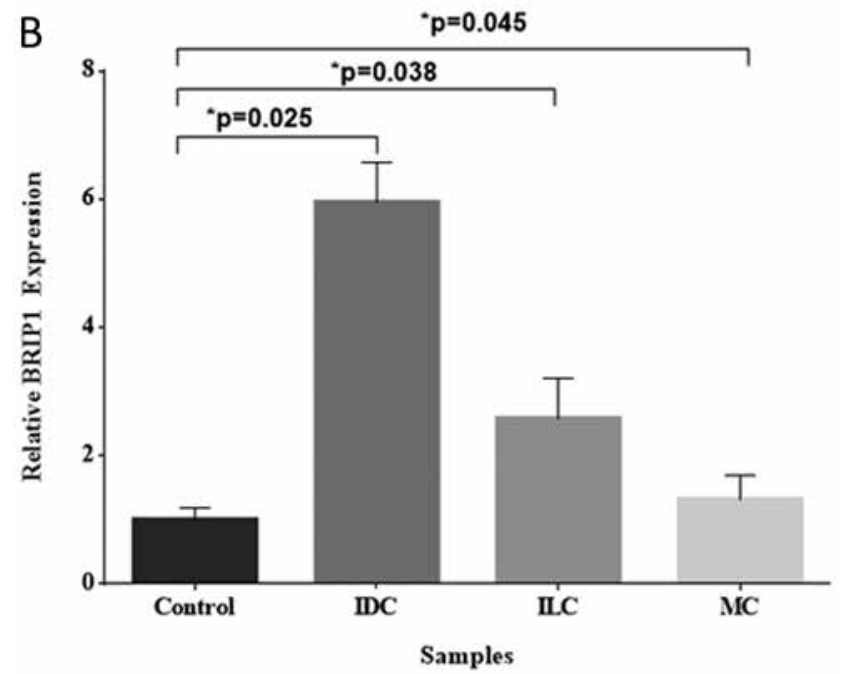

Figure 3

(A) Analysis of BRIP1 expression in the different stages (1-4) of breast cancer by quantitative RT-PCR in breast tissue samples. RT-qPCR was carried out on breast tissue samples and expression was compared to the normal/benign breast tissue samples. As the stage of the tumor increased, $B R I P 1$ expression also increased in comparison to normal/benign breast tissue samples $(P<0.05)$. (B) Analysis of $B R I P 1$ expression based on the histology of breast cancer by quantitative RT-PCR in breast tissue samples. RT-qPCR was carried out on breast tissue samples and expression was compared to the normal/benign breast tissue samples. When divided by invasive ductal, invasive lobular and metaplastic carcinoma, BRIP1 was highly expressed in the invasive ductal followed by the invasive lobular and metaplastic carcinoma in comparison to normal/benign breast tissue samples $(P<0.05)$.

As indicated in Table 2, more than half of the patients were below the age of 50 years and presented with invasive phenotype and more lymph node involvement. Similarly, previous data showed that women affected with breast cancer at a younger age tend to have an advanced invasive pathological type, higher tumor grade and higher rates of

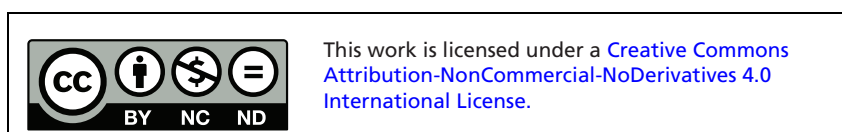


A

$$
\text { Benign Breast Tissue MCF-7 }
$$

MDA-MB-231

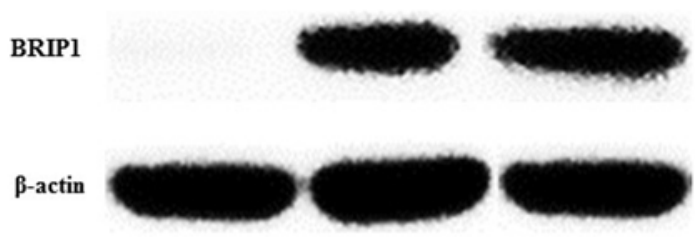

B

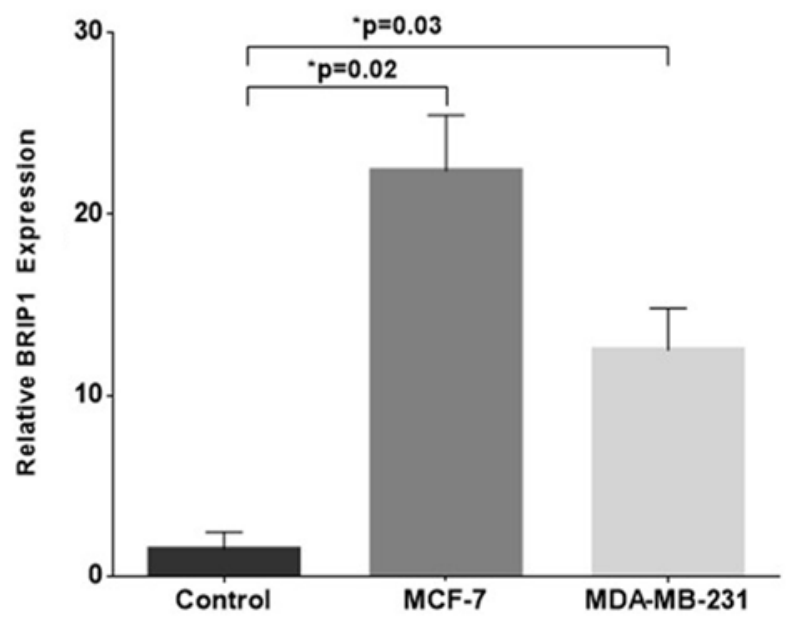

Figure 4

Validation of BRIP1 by Western blot in breast cancer cell lines.

(A) Immunoblotting analysis showed elevated BRIP1 expression in breast cancer cell lines. $\beta$-Actin was used as a control for loading.

(B) Quantification showed that MCF-7 displayed a 14.9-fold increase and MDA-MB-231 displayed an 8.2-fold increase in BRIP1 expression as compared to the benign/normal breast tissue $(P<0.05)$.

lymph node positivity $(8,9,10)$. The majority of patients $(84 \%)$ lacked a family history and failed the routine $B R C A 1 / 2$ clinical test, indicating the lack of inherited BRCA1/2 mutations, and therefore, unlikely to play a key role in the development of sporadic breast tumors $(11,12)$. However, these sporadic cancers could possibly have the $B R C A$ ness phenotype $(13,14)$, which prompted us to look for other genes with a role in the onset of breast cancer either independently or in association with $B R C A 1 / 2$, such as the role played by genetic modifiers (15). One potential candidate interacting with $B R C A 1 / 2$ to regulate DNA repair and cell cycle was identified as BRIP1 gene, displaying 5-fold expression in the breast tumors as compared to the normal/benign tissue (Fig. 1).

Validation analysis using RT-qPCR (Fig. 2B, $P<0.01$ ) and Western blot analyses (Fig. 5, $P<0.0001$ ) carried out on tumor as well as benign tissue samples showed an overexpression of BRIP1 in tumor samples as compared to benign samples; a characteristic feature of oncogenes. Results were consistent with the microarray analysis.

http://www.endocrineconnections.org https://doi.org/10.1530/EC-17-0173

(c) 2018 The authors Published by Bioscientifica Ltd
A
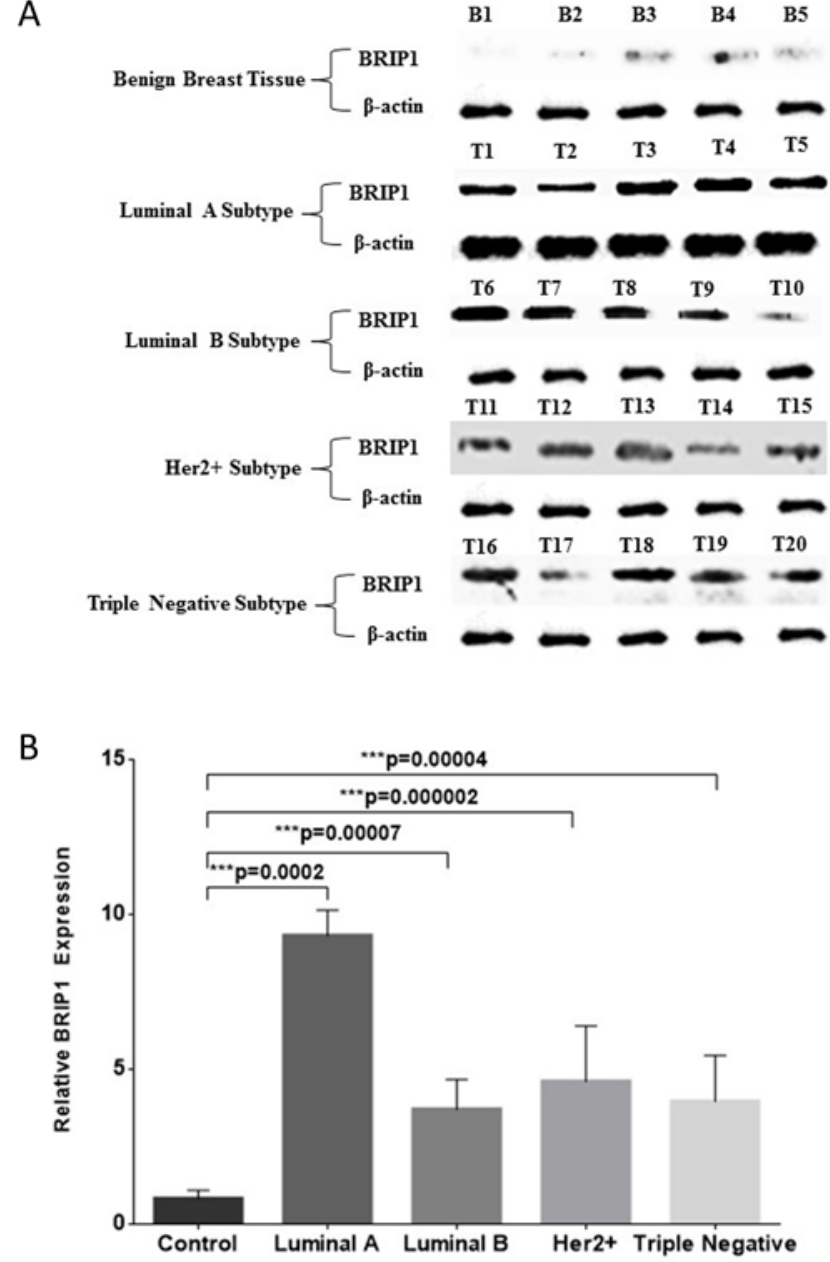

Figure 5

Validation of BRIP1 by Western blot in breast tissue samples.

(A) Validation was carried out for all the 42 tumor and 21 normal/benign tissue samples, at the protein levels by Western blotting analysis. For the benign samples, the five wells correspond to the 5 benign tissue samples (B1-B5). For the Luminal A subtype, the five wells correspond to the 5 tumor tissue samples belonging to the Luminal A subtype (T1-T5); for the Luminal B subtype, the five wells correspond to the 5 tumor tissue samples belonging to the Luminal B subtype (T6-T10). For the Her2+ subtype, the five wells correspond to the 5 tumor tissue samples belonging to the Her2+ subtype (T11-T15) and for the triple-negative subtype, the five wells correspond to the 5 tumor tissue samples belonging to the triple-negative subtype (T16-T20). The same description has been added into the figure legend. (B) Quantification BRIP1 expression was the highest in Luminal A subtype (11.43-fold), followed by Luminal B (4.54-fold), triple-negative (4.86-fold) and Her2+ (5.6-fold) subtypes $(P<0.0001)$.

Although BRIP1 is often described as a tumor suppressor gene, our present data are rather compatible with an oncogenic role, suggesting its dual role in cancer as a TSG but also as an oncogene. Interestingly, a study on the TSG TP53 showed that an overexpression at the mRNA levels is independent of the presence or absence of mutations. This was considered as an early event, not dependent on

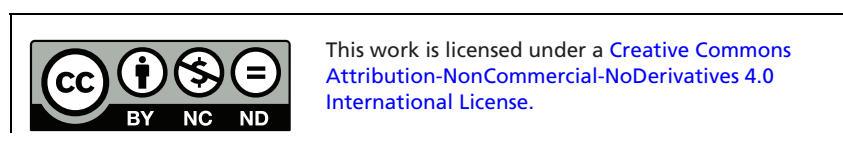




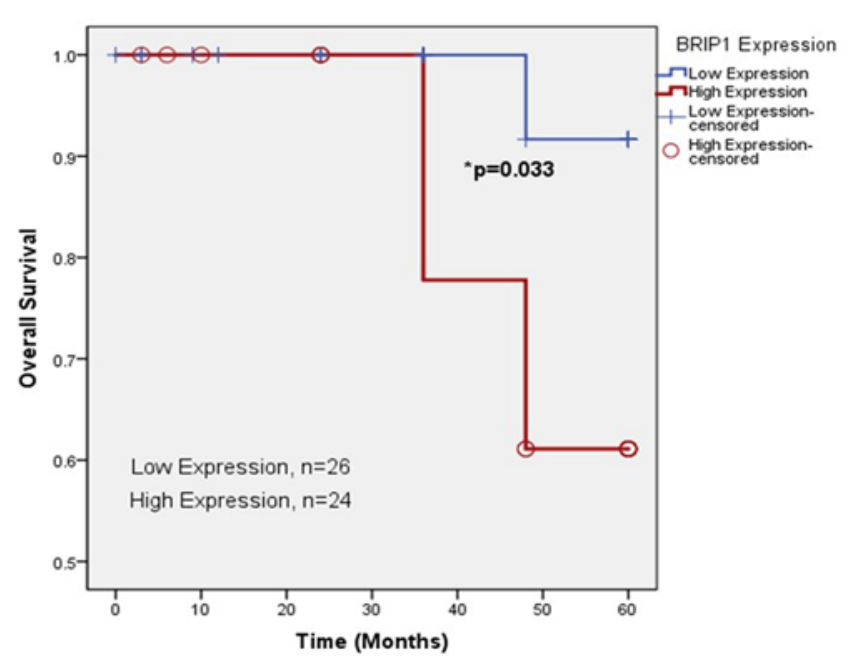

Figure 6

OS in patients expressing BRIP1. Kaplan-Meier estimates of 5-year OS according to $B R I P 1$ expression. High expression of BRIP1 significantly correlated with poor OS and prognosis $(P<0.05)$.

the stage of colon cancer and suggesting that p53, tumor suppressor role may turn to an oncogenic role $(16,17,18)$.

RT-qPCR (Fig. 2A, $P<0.05$ ) and Western blot analyses (Fig. $4, P<0.05)$ in breast cancer cell lines (MCF-7 and MDA-MB-231) depicted overexpression of BRIP1 in MCF-7 followed by MDA-MB-231; results similar to a study where BRIP1 was expressed in MCF-7 and absent in MDA-MB-231 (20). Furthermore, BRIP1 knockdown by siRNA in cells with amplification of BRIP1 (HCC-1954 and MCF-7) showed reduced cellular growth and proliferation as compared to cells lacking BRIP1 amplification (MDA-MB-231 and MCF10A) (20). Moreover, along with MCF-7, another breast cancer cell line, BT474 also displayed BRIP1 amplification (21). Interestingly, another study showed overexpression of BRIP1 to enhance malignancy of breast cancer cells and its knockdown reduced bone metastasis (22), which is in support of BRIP1 as an oncogene.

To further explain the role of BRIP1 in breast cancer, immunohistochemistry was performed on formalin-fixed paraffin-embedded tissues from breast cancer. BRIP1 expression was higher in breast cancer as compared to normal breast (data not shown), in accordance with our RT-qPCR, where BRIP1 expression increased with increase in grade of breast cancer (Fig. 3, $P<0.05$ ). Similarly, a study on 101 invasive breast cancers showed that BRIP1 expression was higher in grade 3 carcinomas as compared to grades 1 and 2 (19).

BRIP1 overexpression results in a gain of function, and it is present in a large complex of transcriptional regulators, co-regulators and chromatin modifiers
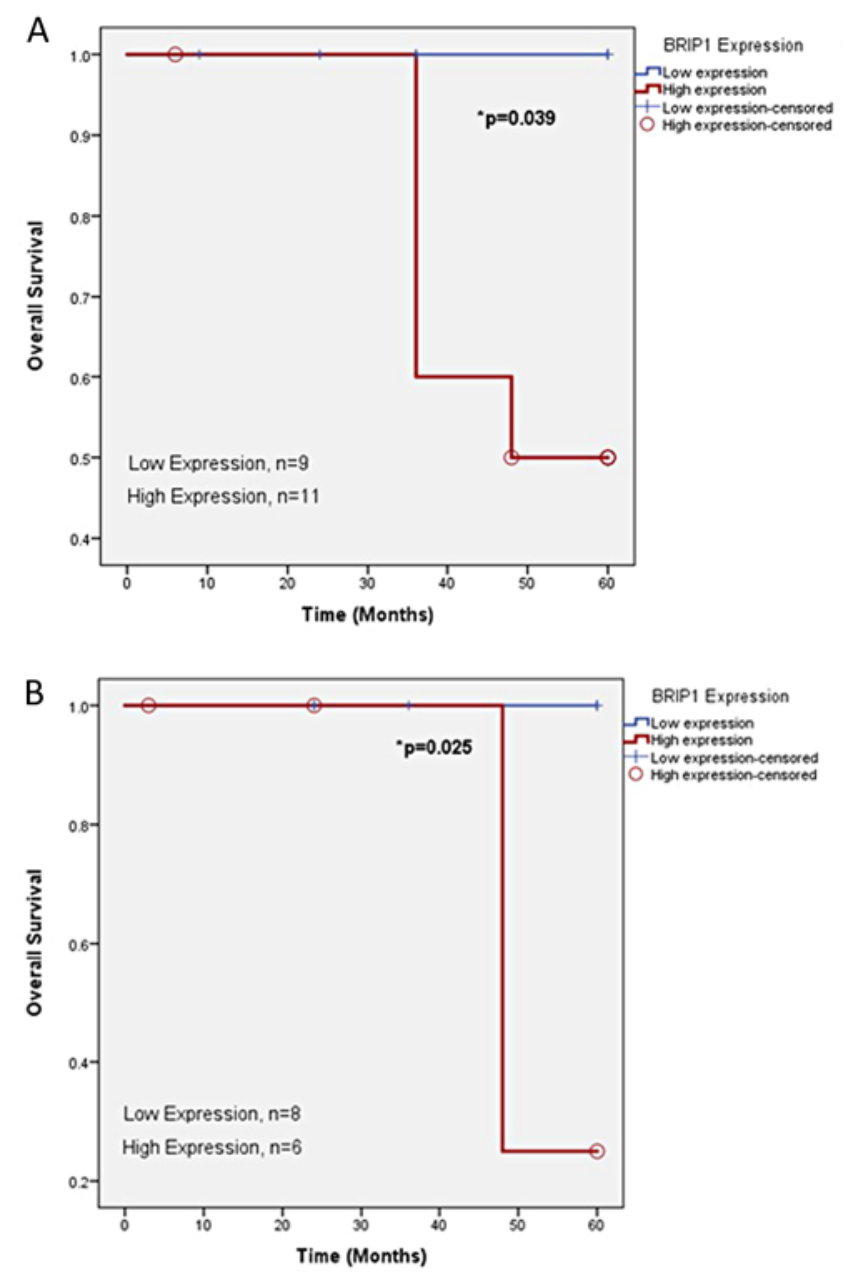

Figure 7

OS in patients belonging to the Luminal A and Luminal B subtypes expressing BRIP1. (A) Kaplan-Meier estimates of 5-year OS according to $B R I P 1$ expression. High expression of BRIP1 in patients belonging to the Luminal A subtype significantly correlated with poor OS and prognosis $(P<0.05)$. (B) Kaplan-Meier estimates of 5 -year OS according to BRIP1 expression. High expression of BRIP1 in patients belonging to the Luminal B subtype significantly correlated with poor OS and prognosis $(P<0.05)$.

(20). BRIP1 regulates the function of several metastatic promoting genes including DUSP1, FHL1, MMP1 and CXCR4. The latter two genes regulate tissue remodeling, tumor progression and invasion (22). Along with this study, two other studies have indicated BRIP1 as a prometastatic gene (23) involved in the regulation of prostate cancer progression (24). Furthermore, BRIP1 was found to be a direct target of the tumor suppressor micro-RNA Let7, a regulator and predictor of $\mathrm{BC}$ metastasis (23). BRIP1 cloned to a GAL4 DNA-binding domain showed strong transcriptional repression independent of its ability to bind BRCA1 (S900A) or its helicase activity (K52R) (20), thus indicating its amplification in sporadic breast cancer. http://www.endocrineconnections.org https://doi.org/10.1530/EC-17-0173
() 2018 The authors Published by Bioscientifica Ltd
This work is licensed under a Creative Commons Attribution-NonCommercial-NoDerivatives 4.0 International License. 
Based on several studies and with the identification of several mutations (truncated, germline and missense), BRIP1 was identified as a breast cancer predisposing gene, and several studies have revealed the association of BRIP1 mutations with breast cancer susceptibility $(4,5,7,25$, 26). Although the pathogenicity of BRIP1 mutations has not been convincingly proved so far, it can possibly help in understanding the non-BRCA1/2 breast cancer cases (27).

In this study, tumors from patients who lack functional $B R C A 1 / 2$ mutations were examined for the presence of aberrations by screening the whole coding area of the BRIP1 gene. We were unable to identify any significant aberration except previously identified polymorphisms (c.2755C > T, c. $-141-64 \mathrm{G}>\mathrm{A}$, c.2637G > A and c.3411T $>$ C) (Table 3).

The first common polymorphism identified in our study was located in the 5'-UTR region (rs2048718) (Table 3) and several earlier studies on this variation were carried out in small as well as large cohorts of breast cancer cases and revealed no association with breast cancer $(7,25,28,29,30,31)$. Similarly, in this study, no association was established between the polymorphism (rs2048718) and breast cancer (Table 3, P>0.05). Although it is generally more frequent in the control series, this 5 'UTR variant affects however cell proliferation and cell growth (32). However, since it is located in the regulatory site, H3K27ac region, which is associated with active enhancer, and it might alter gene expression under the influence of environmental factors.

We also identified a non-synonymous polymorphism (rs4986764) (Table 3) in exon 19 and lacked significant association with breast cancer (Table $3, P>0.05$ ). Similar to our results, studies indicated that the common variant, rs4986764 (p.Ser919Pro), found in the BRCA1-binding domain (33), lack significant associations with breast cancer risk $(4,7,28,29,33,34,35,36,37)$. Curiously, incomplete segregation patterns were identified for susceptibility alleles that can be associated with breast cancer risk (38), suggesting that further analysis of the identified variants, rs4986764 and rs2048718 are needed.

We further identified two synonymous polymorphisms rs4986765 and rs4986763 in exon 19 and 20, respectively (Table 3). These polymorphisms are characterized by the tendency to decrease the binding of the splicing factor, SC35, which is required for the formation of the earliest ATP-dependent splicing complex. This interacts with the spliceosomal components bound to both the 5 '- and 3 '-splice sites of BRIP1 during spliceosome assembly (7). Hence, the two silent mutations (rs4986765, rs4986763) could be involved in the repression or promotion of splicing or alternative splicing of the BRIP1 gene (7). Although these alterations have been investigated in several breast cancer case-control studies to determine their association with breast cancer susceptibility, no studies have been performed so far to demonstrate a significant association of these silent variants with breast cancer $(7,29,33,34,35,36,39)$. This study showed no significant association between the two polymorphisms and the presence of breast cancer (Table $3, P>0.05$ ).

In the present cohort, 24 patients overexpressed BRIP1, while 26 lacked this expression. We further found overexpression of BRIP1 to be associated with poor OS and poor prognosis $(P<0.05$, Fig. 6). We also analyzed the OS in the Luminal A and B molecular subtypes and found BRIP1 overexpression associated with poor OS in patients belonging to both Luminal A and B subtypes $(P<0.05$, Fig. 7A and B). Our data are similar to those reported on colorectal cancer, where BRIP1 overexpression correlated with poor recurrence-free survival (40). Also, elevated expression of BRIP1 was observed in high-grade breast tumors correlated with an unfavorable outcome (19). Due to small number of patients in the Her2+ and triple-negative subtypes, survival analysis could not be performed and needs further evaluation.

Several studies focused on developing suitable inhibitors targeting BRIP1 to guide the design of appropriate therapeutic strategies against cancer. Small molecules targeting BRIP1 signaling pathways such as Werner syndrome (WRN) helicase inhibitor have been developed $(41,42,43)$. In a recent study, high BRIP1 expression was associated with poor responsiveness of 5-FU in colorectal cancer (40). In gastric tumors, 5-FU reduced BRIP1 expression and increased sensitivity to oxaliplatin in gastric tumors (44), suggesting a combination of fluoropyrimidine and platinum agents for the treatment of gastric carcinomas (45). Furthermore, based on BRIP1's interaction with BLM, BLM helicase inhibitors could promote sister chromatid exchange (46).

PARP1 inhibitors involved in repairing singlestrand breaks and sensitizing BRIP1-induced tumors are additional approaches being introduced (27). Moreover, cells lacking BRIP1 are sensitive to treatment with cisplatin (47). BRIP1 is involved in repairing DNA inter-strand crosslinks and plays a role in G4-DNA, thus indicating that BRIP1-induced tumors is sensitive to telomestatin, a G4-DNA ligand regulating the stabilization of G4-DNA structures (27). These strategies highlight the importance of understanding the underlying mechanisms of BRIP1 in cancer to establish appropriate and efficient therapeutic 
strategies. Furthermore, enzymes (S990A) targeting BRIP1 signaling pathways particularly involved in over-reactivity of helicases such as Fe-S domain can pave the way toward the design of useful strategies for cancer treatment (27).

\section{Conclusion}

The prevailing scenario of breast cancer disease in this region of the Middle East (Oman) seems to be of sporadic nature, with the absence of the family history in the majority of cases. One of the limitations of this study was the lack of information about the BRCA1/2 status of the patients, due to ethical regulations and hence those patients who could be carriers of rare $B R C A 1 / 2$ variants were not known. In addition, social stigma associated with the results after the test is another reason to refrain patients from taking the test (48). Furthermore, this test is not cost-effective and hence, a proportion of patients are unable to afford it. This situation may change as the technology and awareness becomes more widespread.

Although small sample size was a limitation in this study, we have demonstrated that BRIP1 gene expression changes in the molecular subtype of breast cancer in Omani patients. Although BRIP1 is a TSG, data presented in this study, indicates BRIP1 to be an oncogene in sporadic cases. Overexpression of certain tumor suppressors including BRIP1, can lead to genomic instability in cellular processing involved in genome integrity maintenance and contribute to the onset and progression of breast malignancy. The present data suggest a putative role of BRIP1 in the onset and progression in breast cancer and the possibility to use this gene as a biomarker. In addition, the small-sample size and lack of patients belonging to the Her2+ and triple-negative subtypes could over-estimate the magnitude of an association and hence, future work will involve a larger cohort to establish a reliable association as well as understand the underlying mechanisms. This can also help to design targeted therapeutic strategies for breast cancer. Furthermore, studies are needed to evaluate the significance of BRIP1 as a predictive and prognostic factor in breast cancer as well as other cancers.

\section{Declaration of interest}

The authors declare that there is no conflict of interest that could be perceived as prejudicing the impartiality of the research reported.

\section{Funding}

This work was supported and funded by 'His Majesty Research Trust Fund', SR/MED/BIOC/14/01.

\section{References}

1 Kao J, Salari K, Bocanegra M, Choi YL, Girard L, Gandhi J, Kwei KA, Hernandez-Boussard T, Wang P, Gazdar AF, et al. Molecular profiling of breast cancer cell lines defines relevant tumor models and provides a resource for cancer gene discovery. PLOS ONE 20094 e6146. (https://doi.org/10.1371/journal.pone.0006146)

2 Holliday DL \& Speirs V. Choosing the right cell line for breast cancer research. Breast Cancer Research 201113 215-215. (https://doi. org/10.1186/bcr2889)

3 Altschul SF, Gish W, Miller W, Myers EW \& Lipman DJ. Basic local alignment search tool. Journal of Molecular Biology 1990215 403-410. (https://doi.org/10.1016/S0022-2836(05)80360-2)

4 Seal S, Thompson D, Renwick A, Elliott A, Kelly P, Barfoot R, Chagtai T, Jayatilake H, Ahmed M, Spanova K, et al. Truncating mutations in the Fanconi anemia J gene BRIP1 are low-penetrance breast cancer susceptibility alleles. Nature Genetics 200638 1239-1241. (https://doi.org/10.1038/ng1902)

5 De Nicolo A, Tancredi M, Lombardi G, Flemma CC, Barbuti S, Di Cristofano C, Sobhian B, Bevilacqua G, Drapkin R \& Caligo MA. A novel breast cancer-associated BRIP1 (FANCJ/BACH1) germ-line mutation impairs protein stability and function. Clinical Cancer Research 200814 4672-4680. (https://doi.org/10.1158/1078-0432. CCR-08-0087)

6 Kennedy J, Abbatiello SE, Kim K, Yan P, Whiteaker JR, Lin C, Kim JS, Zhang Y, Wang X, Ivey RG, et al. Demonstrating the feasibility of large-scale development of standardized assays to quantify human proteins. Nature Methods 201411 149-155. (https://doi.org/10.1038/ nmeth.2763)

7 Guenard F, Labrie Y, Ouellette G, Joly Beauparlant C, Simard J, Durocher F \& INHERIT BRCAs. Mutational analysis of the breast cancer susceptibility gene BRIP1/BACH1/FANCJ in high-risk nonBRCA1/BRCA2 breast cancer families. Journal of Human Genetics 2008 53 579-591. (https://doi.org/10.1007/s10038-008-0285-z)

8 Nixon AJ, Neuberg D, Hayes DF, Gelman R, Connolly JL, Schnitt S, Abner A, Recht A, Vicini F \& Harris JR. Relationship of patient age to pathologic features of the tumor and prognosis for patients with stage I or II breast cancer. Journal of Clinical Oncology 199412 888-894. (https://doi.org/10.1200/JCO.1994.12.5.888)

9 Maggard MA, O'Connell JB, Lane KE, Liu JH, Etzioni DA \& Ko CY. Do young breast cancer patients have worse outcomes? Journal of Surgical Research 2003113 109-113. (https://doi.org/10.1016/S00224804(03)00179-3)

10 Fredholm H, Eaker S, Frisell J, Holmberg L, Fredriksson I \& Lindman H. Breast cancer in young women: poor survival despite intensive treatment. PLoS ONE 20094 e7695. (https://doi. org/10.1371/journal.pone.0007695)

11 Alkam Y. Protein expression and methylation of DNA repair genes hMLH1, hMSH2, MGMT and BRCA1 and their correlation with clinicopathological parameters and prognosis in basal-like breast cancer. Histopathology 201363 713-725. (https://doi.org/10.1111/ his.12220)

12 Ignatov T, Schinlauer A, Costa SD, Roessner A, Kalinski T \& Bischoff J. BRCA1 promoter methylation is a marker of better response to anthracycline-based therapy in sporadic TNBC. Breast Cancer Research and Treatment 2013141 205-212. (https://doi. org/10.1007/s10549-013-2693-9)

13 Akashi-Tanaka S, Watanabe C, Takamaru T, Kuwayama T, Ikeda M, Ohyama H, Mori M, Yoshida R, Hashimoto R, Terumasa S, et al. BRCAness predicts resistance to taxane-containing regimens in triple negative breast cancer during neoadjuvant chemotherapy. Clinical Breast Cancer 201515 80-85. (https://doi.org/10.1016/j. clbc.2014.08.003)

14 Turner N, Tutt A \& Ashworth A. Hallmarks of 'BRCAness' in sporadic cancers. Nature Reviews Cancer 20044 814-819. (https://doi. org/10.1038/nrc1457)

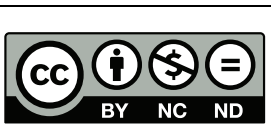

This work is licensed under a Creative Commons Attribution-NonCommercial-NoDerivatives 4.0 International License. 
15 Peterlongo P, Chang-Claude J, Moysich KB, Rudolph A, Schmutzler RK, Simard J, Soucy P, Eeles RA, Easton DF, Hamann U, et al. Candidate genetic modifiers for breast and ovarian cancer risk in BRCA1 and BRCA2 mutation carriers. Cancer Epidemiology Biomarkers and Prevention 201524 308-316. (https://doi.org/10.1158/1055-9965. EPI-14-0532)

16 el-Mahdani N, Vaillant JC, Guiguet M, Prévot S, Bertrand V, Bernard C, Parc R, Béréziat G \& Hermelin B. Overexpression of p53 mRNA in colorectal cancer and its relationship to p53 gene mutation. British Journal of Cancer 199775 528-536. (https://doi. org/10.1038/bjc.1997.92)

17 Walerych D, Napoli M, Collavin L \& Del Sal G. The rebel angel: mutant p53 as the driving oncogene in breast cancer. Carcinogenesis 201233 2007-2017. (https://doi.org/10.1093/carcin/bgs232)

18 Norberg T, Klaar S, Kärf G, Nordgren H, Holmberg L \& Bergh J. Increased p53 mutation frequency during tumor progression-results from a breast cancer cohort. Cancer Research 200161 8317-8321.

19 Eelen G, Vanden Bempt I, Verlinden L, Drijkoningen M, Smeets A, Neven P, Christiaens MR, Marchal K, Bouillon R \& Verstuyf A. Expression of the BRCA1-interacting protein Brip1/BACH1/FANCJ is driven by E2F and correlates with human breast cancer malignancy. Oncogene 200827 4233-4241. (https://doi.org/10.1038/onc.2008.51)

20 Lee AD. Structural Rearrangements in DNA Repair Genes in Breast Cancer. Pittsburgh, PA, USA: University of Pittsburgh, 2013.

21 Sinclair C, Rowley M, Naderi A \& Couch F. The 17q23 amplicon and breast cancer. Breast Cancer Research and Treatment 200378 313-322. (https://doi.org/10.1023/A:1023081624133)

22 Liang Y, Wu H, Lei R, Chong RA, Wei Y, Lu X, Tagkopoulos I, Kung SY, Yang Q, Hu G, et al. Transcriptional network analysis identifies BACH1 as a master regulator of breast cancer bone metastasis. Journal of Biological Chemistry 2012287 33533-33544. (https://doi.org/10.1074/jbc.M112.392332)

23 Yun J, Frankenberger CA, Kuo WL, Boelens MC, Eves EM, Cheng N, Liang H, Li WH, Ishwaran H, Minn AJ, et al. Signalling pathway for RKIP and Let-7 regulates and predicts metastatic breast cancer. EMBO Journal 201130 4500-4514. (https://doi.org/10.1038/ emboj.2011.312)

24 Alvarez A \& Woolf P. RegNetB: predicting relevant regulator-gene relationships in localized prostate tumor samples. BMC Bioinformatics 201112 1-7. (https://doi.org/10.1186/1471-2105-12-1)

25 Sigurdson A, Hauptmann M, Chatterjee N, Alexander BH, Doody MM, Rutter JL \& Struewing JP. Kin-cohort estimates for familial breast cancer risk in relation to variants in DNA base excision repair, BRCA1 interacting and growth factor genes. BMC Cancer 20044 9. (https://doi.org/10.1186/1471-2407-4-9)

26 Vahteristo P, Yliannala K, Tamminen A, Eerola H, Blomqvist C \& Nevanlinna H. BACH1 Ser919Pro variant and breast cancer risk. BMC Cancer 20066 19. (https://doi.org/10.1186/1471-2407-6-19)

27 Cantor SB \& Guillemette S. Hereditary breast cancer and the BRCA1associated FANCJ/BACH1/BRIP1. Future Oncology 20117 253-261. (https://doi.org/10.2217/fon.10.191)

28 Frank B, Hemminki K, Meindl A, Wappenschmidt B, Sutter C, Kiechle M, Bugert P, Schmutzler RK, Bartram CR \& Burwinkel B. BRIP1 (BACH1) variants and familial breast cancer risk: a case-control study. BMC Cancer 20077 83. (https://doi. org/10.1186/1471-2407-7-83)

29 Rutter JL, Smith AM, Dávila MR, Sigurdson AJ, Giusti RM, Pineda MA, Doody MM, Tucker MA, Greene MH, Zhang J, et al. Mutational analysis of the BRCA1-interacting genes ZNF350/ZBRK1 and BRIP1/BACH1 among BRCA1 and BRCA2-negative probands from breast-ovarian cancer families and among early-onset breast cancer cases and reference individuals. Human Mutation 200322 121-128. (https://doi.org/10.1002/humu.10238)

30 Song H, Ramus SJ, Kjaer SK, Hogdall E, Dicioccio RA, Whittemore AS, McGuire V, Hogdall C, Jacobs IJ, Easton DF, et al. Tagging single nucleotide polymorphisms in the BRIP1 gene and susceptibility to breast and ovarian cancer. PLoS ONE 20072 e268. (https://doi. org/10.1371/journal.pone.0000268)

31 Pharoah PDP, Tyrer J, Dunning AM, Easton DF, Ponder BA \& SEARCH Investigators. Association between common variation in 120 candidate genes and breast cancer risk. PLoS Genetics 20073 e42. (https://doi.org/10.1371/journal.pgen.0030042)

32 Belanger H BP, Moreau C, Labuda D, Hudson TJ \& Sinnett D. Functional promoter SNPs in cell cycle checkpoint genes. Human Molecular Genetics 200514 2641-2648 (https://doi.org/10.1093/hmg/ ddi298)

33 Cantor SB, Bell DW, Ganesan S, Kass EM, Drapkin R, Grossman S, Wahrer DC, Sgroi DC, Lane WS, Haber DA, et al. BACH1, a novel helicase-like protein, interacts directly with BRCA1 and contributes to its DNA repair function. Cell 2001105 149-160. (https://doi. org/10.1016/S0092-8674(01)00304-X)

34 Karppinen SM, Vuosku J, Heikkinen K, Allinen M \& Winqvist R. No evidence of involvement of germline BACH1 mutations in Finnish breast and ovarian cancer families. European Journal of Cancer 2003 39 366-371. (https://doi.org/10.1016/S0959-8049(02)00498-7)

35 Luo L, Lei H, Du Q, von Wachenfeldt A, Kockum I, Luthman H, Vorechovsky I \& Lindblom A. No mutations in the BACH1 gene in BRCA1 and BRCA2 negative breast-cancer families linked to 17q22. International Journal of Cancer 200298 638-639. (https://doi. org/10.1002/ijc.10214)

36 Vahteristo P, Yliannala K, Tamminen A, Eerola H, Blomqvist C \& Nevanlinna H. BACH1 Ser919Pro variant and breast cancer risk. BMC Cancer 20066 1-7. (https://doi.org/10.1186/1471-2407-6-1)

37 García-Closas M, Egan K, Newcomb P, Brinton LA, Titus-Ernstoff L, Chanock S, Welch R, Lissowska J, Peplonska B, SzeszeniaDabrowska N, et al. Polymorphisms in DNA double-strand break repair genes and risk of breast cancer: two population-based studies in USA and Poland, and meta-analyses. Human Genetics 2006119 376-388.

38 Rahman N, Seal S, Thompson D, Kelly P, Renwick A, Elliott A, Reid S, Spanova K, Barfoot R, Chagtai T, et al. PALB2, which encodes a BRCA2-interacting protein, is a breast cancer susceptibility gene. Nature Genetics 200739 165-167. (https://doi.org/10.1038/ng1959)

39 Lewis A, Flanagan J, Marsh A, Pupo GM, Mann G, Spurdle AB, Lindeman GJ, Visvader JE, Brown MA, Chenevix-Trench G, et al. Mutation analysis of FANCD2, BRIP1/BACH1, LMO4 and SFN in familial breast cancer. Breast Cancer Research 20057 R1005-R1016. (https://doi.org/10.1186/bcr1336)

40 Nakanishi R, Kitao H, Fujinaka Y, Yamashita N, Iimori M, Tokunaga E, Yamashita N, Morita M, Kakeji Y \& Maehara Y. FANCJ expression predicts the response to 5-fluorouracil-based chemotherapy in MLH1-proficient colorectal cancer. Annals of Surgical Oncology 201219 3627-3635. (https://doi.org/10.1245/ s10434-012-2349-8)

41 Aggarwal M, Banerjee T, Sommers JA \& Brosh JRM. Targeting an Achilles' heel of cancer with a WRN helicase inhibitor. Cell Cycle 201312 3329-3335. (https://doi.org/10.4161/cc.26320)

42 Aggarwal M, Banerjee T, Sommers JA, Iannascoli C, Pichierri P, Shoemaker RH \& Brosh RM Jr. Werner syndrome helicase has a critical role in DNA damage responses in the absence of a functional fanconi anemia pathway. Cancer Research 201373 5497-5507. (https://doi.org/10.1158/0008-5472.CAN-12-2975)

43 Aggarwal M, Sommers JA, Shoemaker RH \& Brosh RM. Inhibition of helicase activity by a small molecule impairs Werner syndrome helicase (WRN) function in the cellular response to DNA damage or replication stress. PNAS 2011108 1525-1530. (https://doi. org/10.1073/pnas.1006423108)

44 Mori R, Yoshida K, Tanahashi T, Yawata K, Kato J, Okumura N, Tsutani Y, Okada M, Oue N \& Yasui W. Decreased FANCJ caused by $5 \mathrm{FU}$ contributes to the increased sensitivity to oxaliplatin in http://www.endocrineconnections.org https://doi.org/10.1530/EC-17-0173 (c) 2018 The authors Published by Bioscientifica Ltd
This work is licensed under a Creative Commons Attribution-NonCommercial-NoDerivatives 4.0 International License. 
gastric cancer cells. Gastric Cancer 201316 345-354. (https://doi. org/10.1007/s10120-012-0191-0)

45 Raymond E, Faivre S, Chaney S, Woynarowski J \& Cvitkovic E. Cellular and molecular pharmacology of oxaliplatin. Molecular Cancer Therapeutics 20021 227-235.

46 Suhasini AN, Rawtani NA, Wu Y, Sommers JA, Sharma S, Mosedale G, North PS, Cantor SB, Hickson ID \& Brosh RM Jr. Interaction between the helicases genetically linked to Fanconi anemia group J and Bloom's syndrome. EMBO Journal 201130 692-705. (https://doi. org/10.1038/emboj.2010.362)
47 Xie J, Litman R, Wang S, Peng M, Guillemette S, Rooney T \& Cantor SB. Targeting the FANCJ-BRCA1 interaction promotes a switch from recombination to poln-dependent bypass. Oncogene 201029 2499-2508. (https://doi.org/10.1038/ onc.2010.18)

48 Cho MK, Sankar P, Wolpe PR \& Godmilow L. Commercialization of BRCA1/2 testing: practitioner awareness and use of a new genetic test. American Journal of Medical Genetics 199983 157-163. (https://doi.org/10.1002/(SICI)1096-8628(19990319)83:3<157::AIDAJMG4>3.0.CO;2-G)

Received in final form 11 October 2017

Accepted 14 November 2017

Accepted Preprint published online 14 November 2017 http://www.endocrineconnections.org https://doi.org/10.1530/EC-17-0173
() 2018 The authors Published by Bioscientifica Ltd International License. 